\title{
Effects of Environmental Temperature on the Dynamics of Ichthyophoniasis in Juvenile Pacific Herring (Clupea pallasii)
}

\author{
Jake L. Gregg, ${ }^{1}$ Johanna J. Vollenweider, ${ }^{2}$ Courtney A. Grady, ${ }^{1}$ Ron A. Heintz, ${ }^{2}$ \\ and Paul K. Hershberger ${ }^{1}$
${ }^{1}$ U.S. Geological Survey, Western Fisheries Research Center, Marrowstone Marine Field Station, 616 Marrowstone Point Road, Nordland, WA 98358, USA
${ }^{2}$ NOAA National Marine Fisheries Service, Alaska Fisheries Science Center, Auke Bay Laboratories, 17109 Pt. Lena Loop Road, Juneau, AK 99801, USA

Correspondence should be addressed to Jake L. Gregg, jgregg@usgs.gov

Received 23 November 2010; Accepted 8 February 2011

Academic Editor: Bernard Marchand

Copyright (C) 2011 Jake L. Gregg et al. This is an open access article distributed under the Creative Commons Attribution License, which permits unrestricted use, distribution, and reproduction in any medium, provided the original work is properly cited.

\begin{abstract}
The effects of temperature and infection by Ichthyophonus were examined in juvenile Pacific herring (Clupea pallasii) maintained under simulated overwinter fasting conditions. In addition to defining parameters for a herring bioenergetics model (discussed in Vollenweider et al. this issue), these experiments provided new insights into factors influencing the infectivity and virulence of the parasite Ichthyophonus. In groups of fish with established disease, temperature variation had little effect on disease outcome. Ichthyophonus mortality outpaced that resulting from starvation alone. In newly infected fish, temperature variation significantly changed the mortality patterns related to disease. Both elevated and lowered temperatures suppressed disease-related mortality relative to ambient treatments. When parasite exposure dose decreased, an inverse relationship between infection prevalence and temperature was detected. These findings suggest interplay between temperature optima for parasite growth and host immune function and have implications for our understanding of how Ichthyophonus infections are established in wild fish populations.
\end{abstract}

\section{Introduction}

Ichthyophonus hoferi, a highly pathogenic parasite of marine and anadromous fishes, is currently ubiquitous in Pacific herring (Clupea pallasii) populations throughout the $\mathrm{NE}$ Pacific [1-3]. Phenotypic [4] and genotypic $[5,6]$ differences among isolates of $I$. hoferi suggest that there are multiple sympatric species in the region. Due to this taxonomic uncertainty, here we refer to the parasite by its generic name. Among wild Pacific herring, the prevalence of infection typically increases with age; consequently, the resulting disease (ichthyophoniasis) is thought to affect primarily older age cohorts [2, 7]. However, the impact of Ichthyophonus infections on juvenile Pacific herring has received little attention. In Atlantic herring (Clupea harengus), it has been suggested that time to mortality is shorter for juveniles than for adults resulting in relatively low, but highly variable, prevalence [8]. Prevalence of infection among young-of-the-year (YOY) herring is typically $3-13 \%$ in the NE Pacific (USGS unpublished data) with infections detected as early as 4 months after hatch [9]. In addition to causing direct mortality from disease, Ichthyophonus infection may predispose juvenile herring to indirect mortality through predation [10], presumably as a result of decreased swimming performance $[11,12]$. This type of indirect mortality is difficult to demonstrate but should be expected considering the extensive tissue damage that can result from ichthyophoniasis. Ichthyophonus invades multiple visceral organs and can appear in the heart within $26 \mathrm{~h}$ after exposure [13]. Kocan et al. [11] reported a $40 \%$ increase in cardiac weight in infected rainbow trout (Oncorhynchus mykiss) resulting from parasite biomass and host inflammatory response. The physiological cost of ichthyophoniasis and resulting reduction in fitness could compound the effects of other environmental and biological stressors experienced by juvenile Pacific herring.

In the NE Pacific, specifically Prince William Sound, the overwinter fast has been identified as a primary factor limiting YOY herring survival [14]. This study and its companion 
(see in Vollenweider et al. this issue) were designed to improve our understanding of the bioenergetic costs of overwinter fasting for juvenile Pacific herring. We were specifically interested in the compounding effects of disease, temperature, and starvation on survival, and the effect of temperature on disease processes. Three experiments were conducted to determine (1) effects of temperature on mortality in fasting Pacific herring with established disease, (2) effects of temperature on disease progression and mortality in fasting Pacific herring immediately after parasite exposure, and (3) effects of temperature on disease progression and mortality in Pacific herring recovering from pre-exposure fast.

\section{Materials and Methods}

2.1. Pacific Herring. To ensure that animals were parasitefree and immunologically naïve at initiation of experiments, a cohort of specific-pathogen-free (SPF) Pacific herring was reared for this study at the USGS Marrowstone Marine Field Station (MMFS) (Nordland, WA, USA). Naturally spawned eggs from wild Pacific herring were collected from the southern Strait of Georgia $\left(48^{\circ} 55.85^{\prime} \mathrm{N}, 122^{\circ} 48.15^{\prime} \mathrm{W}\right)$ on 5 May 2008 and transported to MMFS where they were held in $270 \mathrm{~L}$ tanks supplied with filtered, UV-irradiated seawater. Eggs hatched on 18 May 2008 and larvae were subsequently moved to $1700 \mathrm{~L}$ tanks where they were fed enriched live feeds (i.e., Brachionus plicatilis and Artemia franciscana) and frozen copepods (Cyclop-eeze, Argent Chemical Laboratories, Redmond, WA, USA) until metamorphosis to juveniles. Juvenile herring were weaned to a krill-meal pellet produced at the USFWS Abernathy Fish Technology Center (Longview, WA, USA) and eventually to commercially available salmon pellet (Bio-Olympic Fry, Bio-Oregon, Longview, WA, USA).

\subsection{Experiment Design and Environment. Three experiments} were performed over an eleven-month period to investigate the effects of fasting and temperature on disease dynamics in Ichthyophonus-infected Pacific herring (Table 1). Two treatments, infected and uninfected, were applied to fasting herring held at each of three temperatures (low, ambient, and high). To control for the effect of fasting, this $2 \times 3$ design was modified with the addition of two fed treatments, infected and uninfected, maintained at ambient temperature. Herring were randomly assigned to triplicate $270 \mathrm{~L}$ tanks in each treatment. Flow through seawater (low, ambient, and high temperature) was delivered to each tank at the rate of $4 \mathrm{~L} \mathrm{~min}^{-1}$. The temperature regulating system allowed temperatures to vary with seasonal seawater temperature, but maintained a relatively consistent separation between low, ambient, and high temperature treatments. Seawater temperatures in low and high treatments were adjusted gradually over the first $24 \mathrm{~h}$ after fish were distributed to replicate tanks. Water temperature was recorded every $30 \mathrm{~min}$ (Hobo Water Temp Pro v2, Onset Computer Corp., Bourne, MA, USA). Temperature treatments will be identified here as the mean temperature that occurred throughout the experimental period.
2.3. Parasite Exposure. Ichthyophonus exposure for herring in infected treatments occurred via intraperitoneal (IP) injection. To obtain stock material for Ichthyophonus inoculum, heart tissues from Ichthyophonus-infected herring (wild and laboratory infected) were cultured in Eagle's minimum essential medium supplemented with fetal bovine serum (5\% $\mathrm{v} / \mathrm{v})$, penicillin $\left(100 \mathrm{IU} \mathrm{mL}^{-1}\right)$, streptomycin $\left(100 \mu \mathrm{g} \mathrm{mL}^{-1}\right)$ and gentamycin $\left(100 \mu \mathrm{g} \mathrm{mL}^{-1}\right)$ and buffered to $\mathrm{pH} 7.8$ with $1 \mathrm{M}$ Tris (MEM). After 2-4 weeks in culture, thousands of Ichthyophonus schizonts (i.e., spherical multinucleate bodies) had grown out of the tissues and were free in the media. Host tissues and medium were removed from these cultures with sterile pipettes, several cultures were combined, and this mixture was diluted in sterile phosphatebuffered saline (PBS) to produce an inoculating solution that contained approximately 2000 schizonts $\mathrm{mL}^{-1}$. Fifty $\mu \mathrm{L}$ of inoculum was then injected into each fish with the goal of introducing 100 schizonts/fish regardless of size. For each experiment, three 50 microliter aliquots were collected during the injection process and schizonts were counted at 40X magnification on an inverted microscope. Final inoculum concentration (i.e. dose) for each experiment was determined by dividing the mean number of schizonts by mean fish weight.

\subsection{Effects of Temperature on Mortality in Fasting Pacific} Herring with Established Disease. Juvenile SPF herring (age = $145 \mathrm{~d}$ ) were inoculated with Ichthyophonus schizonts (mean $=174$ schizonts fish $^{-1}$ ) and placed in a $760 \mathrm{~L}$ holding tank. Nineteen days post-exposure (DPE), when external signs of ichthyophoniasis (i.e. black skin ulcerations) were evident in many individuals, herring from this tank and a corresponding tank containing uninfected controls were distributed to triplicate $260 \mathrm{~L}$ tanks ( $n=47$ to $52 \mathrm{fish} / \operatorname{tank}$ ) at each of three temperatures, $6.7^{\circ} \mathrm{C}$ (low), $9.3^{\circ} \mathrm{C}$ (ambient), and $12.3^{\circ} \mathrm{C}$ (high), and fasting was initiated. Additional $9.3^{\circ} \mathrm{C}$ (ambient) treatment groups with infected and uninfected herring were fed to satiation daily. The experiment was terminated $80 \mathrm{DPE}$.

2.5. Effects of Temperature on Disease Progression and Mortality in Fasting Pacific Herring Immediately after Parasite Exposure. Juvenile SPF herring (age $=241 \mathrm{~d})$ were injected with Ichthyophonus schizonts (mean $=167$ schizonts fish ${ }^{-1}$ ) or PBS and immediately distributed to triplicate tanks $(n=$ 49 to $51 \mathrm{fish} /$ tank) at each of three temperatures: $5.6^{\circ} \mathrm{C}$ (low), $7.9^{\circ} \mathrm{C}$ (ambient), and $12.4^{\circ} \mathrm{C}$ (high), and fasting was initiated. Additional $7.9^{\circ} \mathrm{C}$ (ambient) treatment groups with infected and uninfected herring were fed to satiation daily. Treatments were terminated between 111 and 127 DPE.

2.6. Effects of Temperature on Disease Progression and Mortality in Pacific Herring Recovering from Pre-Exposure Fast. Feed was withheld from 607 SPF herring held in two 760 $\mathrm{L}$ tanks and a second group of 300 SPF herring in a single $760 \mathrm{~L}$ tank were fed to excess $3 \mathrm{x}$ week $^{-1}$ (i.e., $>10 \%$ biomass per feeding). The experiment was initiated after $56 \mathrm{~d}$ when herring from the fasted colony were injected with 
Table 1: Clupea pallasii. Summary data for 3 Ichthyophonus experiments conducted in this study. Pacific herring in experiments 1 and 2 fasted during challenge, herring in experiment 3 fasted for $56 \mathrm{~d}$ prior to challenge and then fed to satiation during challenge.

\begin{tabular}{|c|c|c|c|c|c|c|c|c|c|c|}
\hline \multirow[b]{2}{*}{ No. } & \multicolumn{2}{|c|}{ Experiment } & \multicolumn{3}{|c|}{ Herring } & \multicolumn{2}{|c|}{ Ichthyophonus } & \multicolumn{3}{|c|}{ Temperature $\left({ }^{\circ} \mathrm{C}\right)^{\mathrm{a}}$} \\
\hline & Disease state & Duration (d) & Age (d) & $\mathrm{FL}(\mathrm{mm})$ & Weight (g) & $\begin{array}{l}\text { Schizonts }^{\mathrm{b}} \text { per } \\
\text { inoculation }\end{array}$ & $\begin{array}{c}\text { Dose } \\
\left(\text { schizonts g }{ }^{-1}\right)^{\mathrm{c}}\end{array}$ & Low & Amb & High \\
\hline (1) & $\begin{array}{l}\text { Diseased: } 19 \mathrm{~d} \\
\text { after exposure }\end{array}$ & 80 & 164 & 44 & 1.0 & 174 & 174 & 6.7 & 9.3 & 12.3 \\
\hline (2) & $\begin{array}{l}\text { Infected: } 1 \mathrm{~d} \\
\text { after exposure }\end{array}$ & 127 & 241 & 70 & 3.6 & 167 & 46 & 5.6 & 7.9 & 12.4 \\
\hline (3) & $\begin{array}{l}\text { Infected: } 1 \mathrm{~d} \\
\text { after exposure }\end{array}$ & 54 & 431 & $92(100)^{\mathrm{d}}$ & $6.5(9.2)^{\mathrm{d}}$ & 112 & $17(12)^{\mathrm{d}}$ & 9.3 & 12.0 & 15.3 \\
\hline
\end{tabular}

${ }^{a}$ Temperature reported is mean of temperature recordings made every 30 minutes during course of challenge.

${ }^{\mathrm{b}}$ Schizonts are multinucleate spherical bodies from in vitro Ichthyophonus cultures, number reported is mean of three $50 \mu \mathrm{L}$ samples.

${ }^{\mathrm{c}}$ Dose $=$ mean number of schizonts divided by mean weight of fish.

${ }^{d}$ Values in parentheses are from group of herring that did not go through prechallenge fast in experiment (3).

either Ichthyophonus or PBS and transferred to triplicate tanks $(N=27$ to 30 fish per tank $)$ at each of three temperatures: $9.3^{\circ} \mathrm{C}$ (low), $12.0^{\circ} \mathrm{C}$ (ambient), and $15.3^{\circ} \mathrm{C}$ (high). Herring from the fed colony were injected with either Ichthyophonus or PBS and transferred to triplicate tanks at $12.0^{\circ} \mathrm{C}$ (ambient). Fish in all treatments (previously fasted and fed) were fed to satiation daily after exposure. Live herring were subsampled $\left(n=2 \operatorname{tank}^{-1}\right)$ for bioenergetic analysis (see in Vollenweider et al. this issue) $31 \mathrm{DPE}$, and the experiment was terminated $54 \mathrm{DPE}$.

2.7. Fish Sampling. A subsample $(n=20$ fish) was taken from pre-experiment pools for fork length (FL) and weight (WT) measurements at the initiation of each experiment. Mortalities in all challenges were removed from tanks daily, and survivors were euthanized with an overdose of tricaine methane sulfonate in buffered seawater at the termination of each experiment. Prevalence of infection and disease was determined among mortalities and survivors from all experiments. Prevalence of infection was determined by in vitro explant culture of heart tissue in MEM. Heart cultures were incubated at $15^{\circ} \mathrm{C}$ and examined microscopically (40x magnification) for the presence of Ichthyophonus schizonts and/or hyphae after $14 \mathrm{~d}$. Culture-positive samples were considered diseased when visible lesions indicative of ichthyophoniasis were observed on the skin and/or heart.

2.8. Statistics. Cumulative mortality was compared between treatments at the midpoint and end of each experiment using a single factor (treatment) ANOVA followed by a Tukey Test for multiple comparisons. Infection and disease prevalence were similarly compared between the Ichthyophonus-exposed treatments. All analyses were conducted using arcsine transformed data. Statistical significance was assigned to comparisons with $P \leq .05$.

\section{Results}

3.1. Mortality in Fasting Pacific Herring with Established Disease. Herring were $44 \mathrm{~mm} \mathrm{FL}(\mathrm{SD}=4.7)$ and $1.0 \mathrm{~g} \mathrm{WT}$
$(\mathrm{SD}=0.38)$ at the initiation of this challenge. A dose of 174 schizonts $\mathrm{g}^{-1}$ successfully established Ichthyophonus infections, and a majority of the infections progressed to overt disease. In Ichthyophonus-exposed groups, infection prevalence ranged from 95.9 to $98.6 \%$ with no significant differences between treatments $\left(F_{0.05(2), 3,8}=1.749, P<.23\right)$. Similarly, prevalence of disease (i.e., clinical signs) among infected fish ranged from 97.0 to $99.3 \%$ with no significant differences between treatments $\left(F_{0.05(2), 3,8}=1.089, P<\right.$ .41). Ichthyophonus was not detected in any herring from unexposed control groups.

Cumulative mortality in infected treatments generally followed a sigmoid pattern reaching $44 \%$ to $55 \%$ by the midpoint of the experiment and $65 \%$ to $98 \%$ by the end (Figure 1). Cumulative mortality varied significantly with treatment at the midpoint of the experiment (day 40; $\left.F_{0.05(2), 7,16}=102.2, P<4.4 \times 10^{-12}\right)$. The Tukey test for multiple comparisons grouped all infected treatments separate from uninfected controls on $40 \mathrm{DPE}$, with no separation due to temperature. Starvation mortality in fasting, uninfected treatments followed a predictable pattern in relation to temperature. At 52, 61, and $72 \mathrm{DPE}$, cumulative mortality reached $10 \%$ in $12.3^{\circ} \mathrm{C}$ (high), $9.3^{\circ} \mathrm{C}$ (ambient), and $6.7^{\circ} \mathrm{C}$ (low) treatments, respectively, and increased exponentially until termination of the experiment (Figures 1(a), 1(b), and 1(c)). Starvation mortality continued in infected treatments late into the challenge preventing a plateau that appeared to be developing in infected treatments around $60 \%$ to $70 \%$. This plateau did develop in the single infected treatment $\left(9.3^{\circ} \mathrm{C}\right)$ that was fed throughout the challenge (Figure 1(d)). At termination of the experiment, significant differences in cumulative mortality did exist between treatments (day 80; $F_{0.05(2), 7,16}=55.3, P<5.0 \times 10^{-10}$ ), but the Tukey test did not group the treatments by infection status as on day 40 . At termination cumulative mortality in fasting uninfected treatments approached or surpassed that resulting from disease alone. Cumulative mortality in the uninfected, fed treatment $\left(9.3^{\circ} \mathrm{C}\right)$ remained below $5 \%$ (Figure $1(\mathrm{~d})$ ).

3.2. Disease Progression and Mortality in Fasting Pacific Herring Immediately after Parasite Exposure. Herring were 


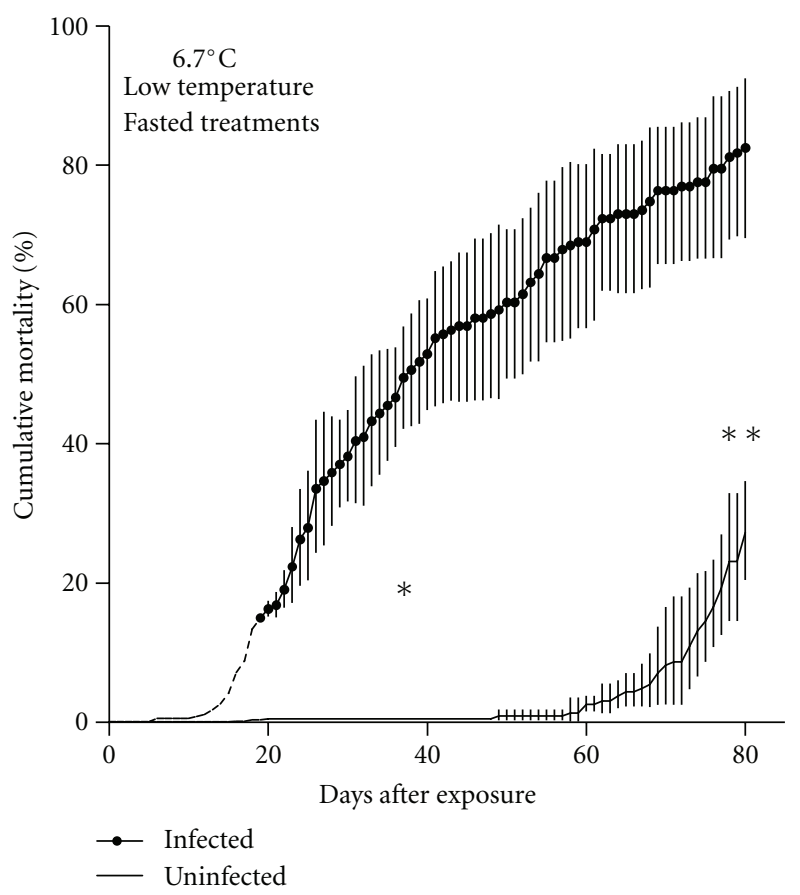

(a)

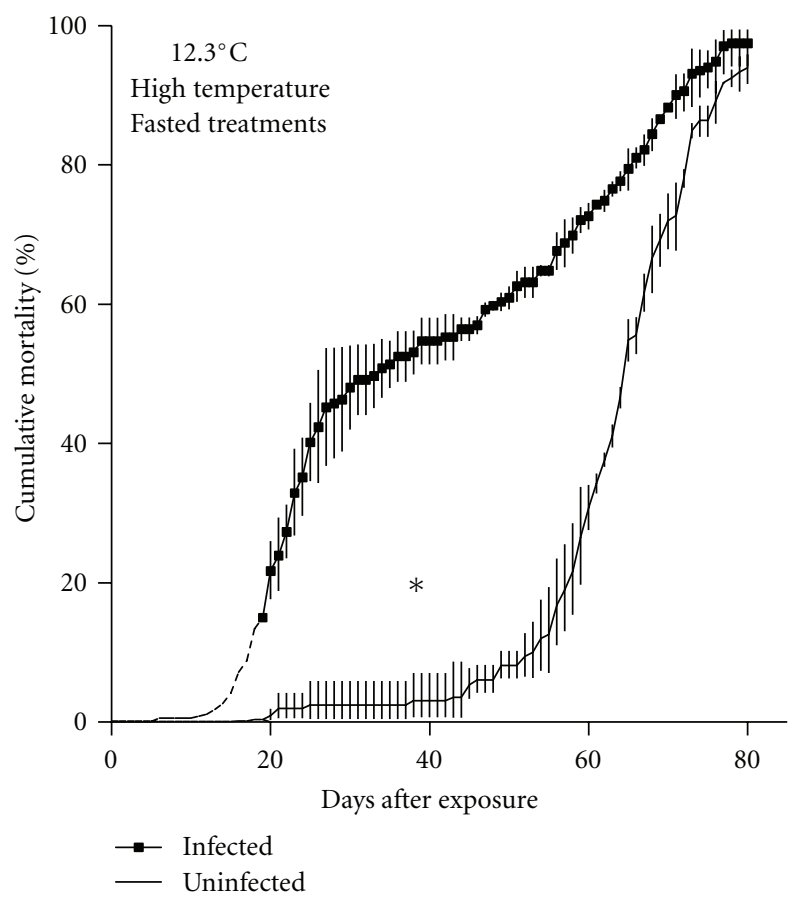

(c)

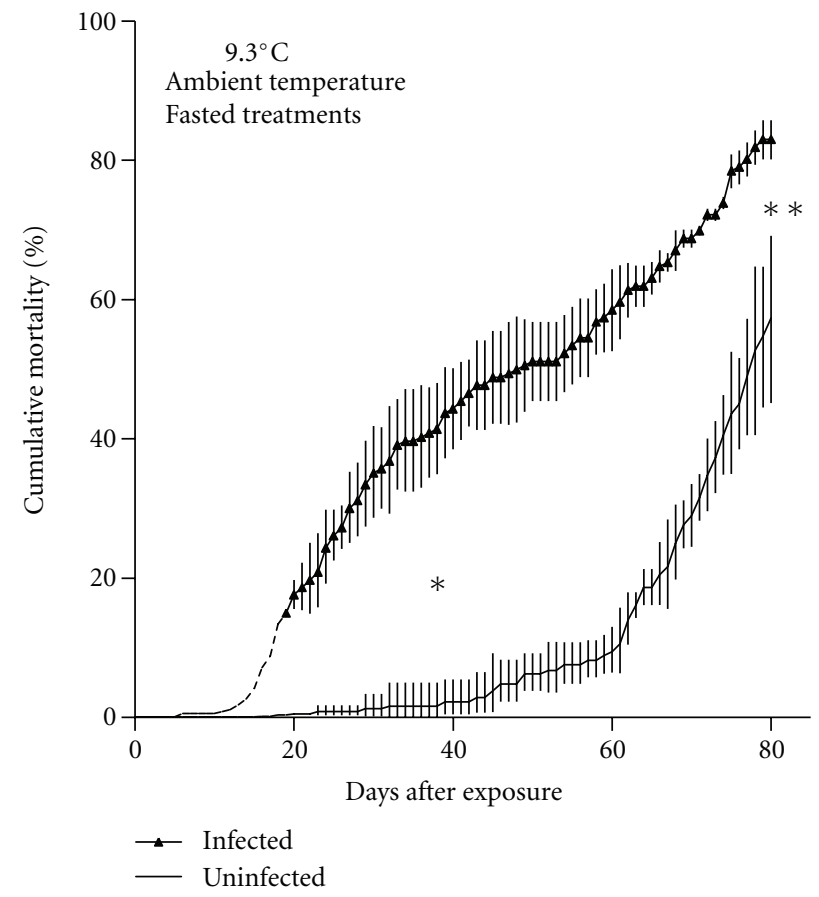

(b)

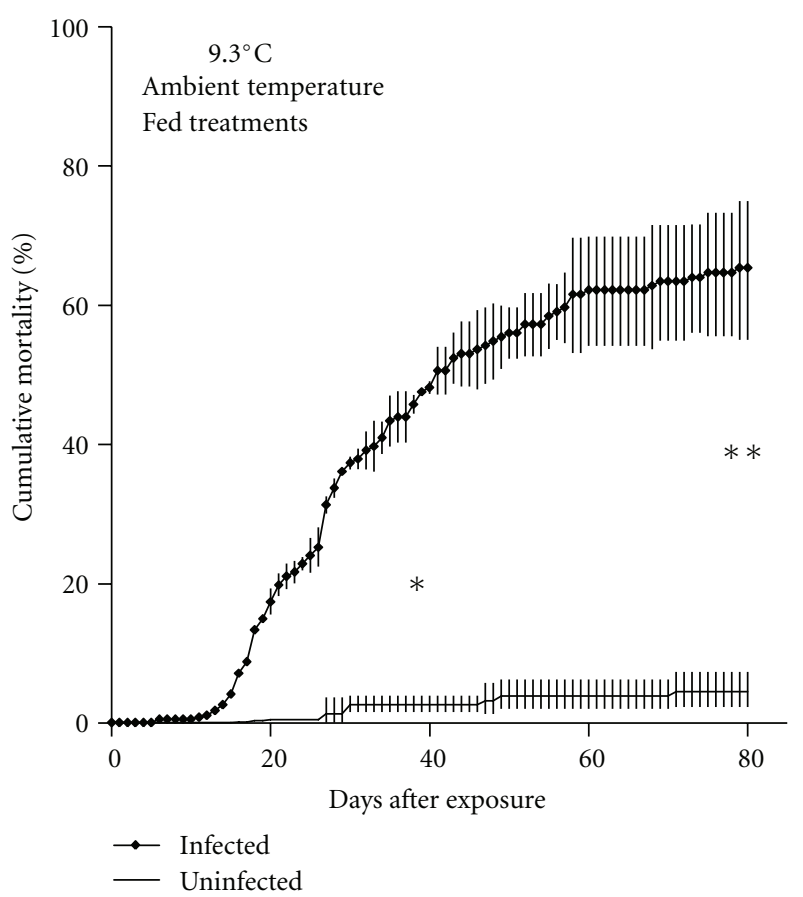

(d)

FIgure 1: Clupea pallasii. Cumulative mortality of diseased (ichthyophoniasis) and control Pacific herring in three temperature treatments. Data in (a), (b), and (c) are from fish undergoing simulated overwinter fast. Data in (d) are from fed treatments. Temperature adjustments were made 19 days after inoculation with Ichthyophonus schizonts. Data are means of 3 replicate tanks in each treatment. Error bars are one SD above and below the mean. Means and SD were calculated from arcsine-transformed data. Mortality data prior to day 19 are from the pools of infected and control fish prior to separation into treatment. Significant differences between infected and uninfected groups (Tukey multiple comparisons) indicated by $*$ and $* *$ for midpoint and end of challenge, respectively. 
$70 \mathrm{~mm}$ FL $(\mathrm{SD}=6.3)$ and $3.6 \mathrm{~g} \mathrm{WT}(\mathrm{SD}=0.97)$ at the initiation of this challenge. A dose of 46 schizonts $\mathrm{g}^{-1}$ successfully established Ichthyophonus infections, and a majority of the infections progressed to overt disease. In Ichthyophonusexposed groups, infection prevalence ranged from $95.4 \%$ to $98.0 \%$ with no significant differences between treatments $\left(F_{0.05(2), 3,8}=1.005, P<.44\right)$. Similarly, prevalence of disease (i.e., clinical signs) among infected fish ranged from 95.1\% to $99.3 \%$ with no significant differences between treatments $\left(F_{0.05(2), 3,8}=1.977, P<.20\right)$. Ichthyophonus was not detected in any herring from PBS-injected control groups.

Disease-related mortality was negated in fasting Pacific herring moved to $5.6^{\circ} \mathrm{C}$ and $12.4^{\circ} \mathrm{C}$ shortly after Ichthyophonus exposure (Figures 2(a) and 2(c)), while the newly exposed Pacific herring remaining at $7.9^{\circ} \mathrm{C}$ displayed mortality kinetics (Figures 2(b) and 2(d)) similar to fish with established disease (Figures 1(b) and 1(d)). Significant difference did occur between treatments at midpoint $\left(F_{0.05(2), 7,16}=\right.$ 11.83, $\left.P<2.8 \times 10^{-5}\right)$ and end $\left(F_{0.05(2), 7,16}=30.45, P<4.3 \times\right.$ $10^{-8}$ ) of the challenge, but these differences were not simply the result of differences between infected and uninfected treatments. Cumulative mortality at $5.6^{\circ} \mathrm{C}$ reached $48.7 \%$ and $45.3 \%$ in infected and uninfected treatments, respectively. Little separation occurred between these treatments at the midpoint or end of the experiment. Similarly, there were no significant differences between uninfected and infected treatments at $12.4^{\circ} \mathrm{C}$, where mortality reached $92.0 \%$ and $96.5 \%$, respectively, by the end of the experiment. Mortality curves in infected groups held at $5.6^{\circ} \mathrm{C}$ and $12.4^{\circ} \mathrm{C}$ were similar to those which resulted from starvation alone (Figures 2(a) and 2(c)), a simple exponential increase. Mortality in herring held at $7.9^{\circ} \mathrm{C}$ after exposure varied significantly with infection status (Figures 2(b) and 2(d)). Cumulative mortality in fed infected herring reached $25.3 \% 55$ DPE and plateaued just below $50 \%$ around 90 DPE. Mortality of fasted infected herring reached $34.6 \% 55$ DPE but did not plateau as starvation mortality (evident in uninfected groups) ensued, pushing cumulative mortality to $83.1 \%$ by the end of the experiment. Fed uninfected fish experienced less than 5\% mortality.

\subsection{Disease Progression and Mortality in Pacific Herring} Recovering from Pre-Exposure Fast. Prevalence of Ichthyophonus infection after IP exposure to schizonts was inversely related to water temperature. Pre-exposure fasting resulted in herring that were $92 \mathrm{~mm} \mathrm{FL}(\mathrm{SD}=11.7)$ and $6.5 \mathrm{~g} \mathrm{WT}$ $(\mathrm{SD}=2.4)$. A dose of 17 schizonts $\mathrm{g}^{-1}$ established infection in $76.3 \%, 53.9 \%$, and $23.9 \%$ of these fish in $9.3^{\circ} \mathrm{C}, 12.0^{\circ} \mathrm{C}$, and $15.3^{\circ} \mathrm{C}$ (low, ambient, and high) treatments, respectively. The pre-exposure fed group was larger $(100 \mathrm{~mm}, \mathrm{SD}=12.3 ; 9.2 \mathrm{~g}$, $\mathrm{SD}=3.2$ ) resulting in a lower dose of 12 schizonts $\mathrm{g}^{-1}$. This dose established infections in $30.9 \%$ of the fish at $12.0^{\circ} \mathrm{C}$. Prevalence of infection varied significantly with treatment (Figure $\left.3 ; F_{0.05(2), 3,8}=5.956, P<.02\right)$. Among infected herring, prevalence of disease (i.e., clinical signs) ranged from $95.0 \%$ to $100 \%$ with no significant differences between treatments $\left(F_{0.05(2), 3,8}=0.668, P<.59\right)$. Ichthyophonus was not detected in any control herring injected with PBS.
Mortality resulting from handling and injection of fish at the initiation of this experiment was very high, most likely due to the weakened condition of the fish at the end of the prechallenge fast, some treatments lost as many as $28 \%$ of fish in first few days after exposure. For this reason, we calculated cumulative mortality based on the fish that remained in the tanks on day 10 and only compared cumulative mortality (ANOVA) at the end of the challenge. Overall, adjusted cumulative mortality was lower and more variable than in the previous two challenges; $6.1 \%$ to $15.9 \%$ in uninfected treatments and $11.8 \%$ to $24.9 \%$ in infected treatments; ANOVA detected no significant differences between treatments $\left(F_{0.05(2), 7,16}=2.23, P<.09\right)$.

\section{Discussion}

Disease processes do vary with temperature in juvenile Pacific herring infected with Ichthyophonus. However, the degree to which changes in temperature alter the outcome (i.e, infection prevalence or cumulative mortality) for Ichthyophonus-infected groups depends on the stage/intensity of the infection. Temperature manipulation had no detectable effect on Ichthyophonus infections that had progressed to overt disease. Mortality in these cases outpaced that which resulted from starvation alone (Figure 1). However, disease outcome was affected when temperature manipulation occurred within $24 \mathrm{~h}$ of Ichthyophonus exposure. Cumulative mortality in high $\left(12.4^{\circ} \mathrm{C}\right)$ and low $\left(5.6^{\circ} \mathrm{C}\right)$ temperature infected treatments was not significantly different from that of corresponding uninfected groups, while mortality kinetics in ambient treatments $\left(7.9^{\circ} \mathrm{C}\right)$ did differ with infection status (Figure 2). Suppression of Ichthyophonus mortality was so complete in high and low temperatures that net Ichthyophonus mortality (i.e., disease mortalitycontrol mortality) remained low throughout the study and at some time points was negative. Slower parasite growth could explain the lower mortality in low temperature treatments, as our experiments were conducted in a range where temperature and Ichthyophonus growth (in vitro) are directly related $[15,16]$. However, if the relationship was simply based on parasite growth, the trend would hold and mortality would increase with increasing temperature, as has been demonstrated in some bacteria-salmonid systems $[17,18]$. Suppressed mortality from ichthyophoniasis in both low and high temperature treatments suggests interplay of temperature optima for parasite growth and host immune function.

Innate and adaptive immune functions of fish are significantly affected by environmental temperature [19-22] . Immunocompetence is generally considered to vary directly with temperature within the homeostatic range of the host; however, there is suggestion that at low temperatures some nonspecific immune functions may increase to compensate for suppression of adaptive immune responses [22]. Complement-mediated lytic activity [23], production of macrophage activating factor [24], natural antibody activity [19], and protection resulting from vaccination [25] have all been shown to increase with increased temperature. The immune response to histozoic parasites includes an innate response at the mucous layer, an innate response in tissues, 


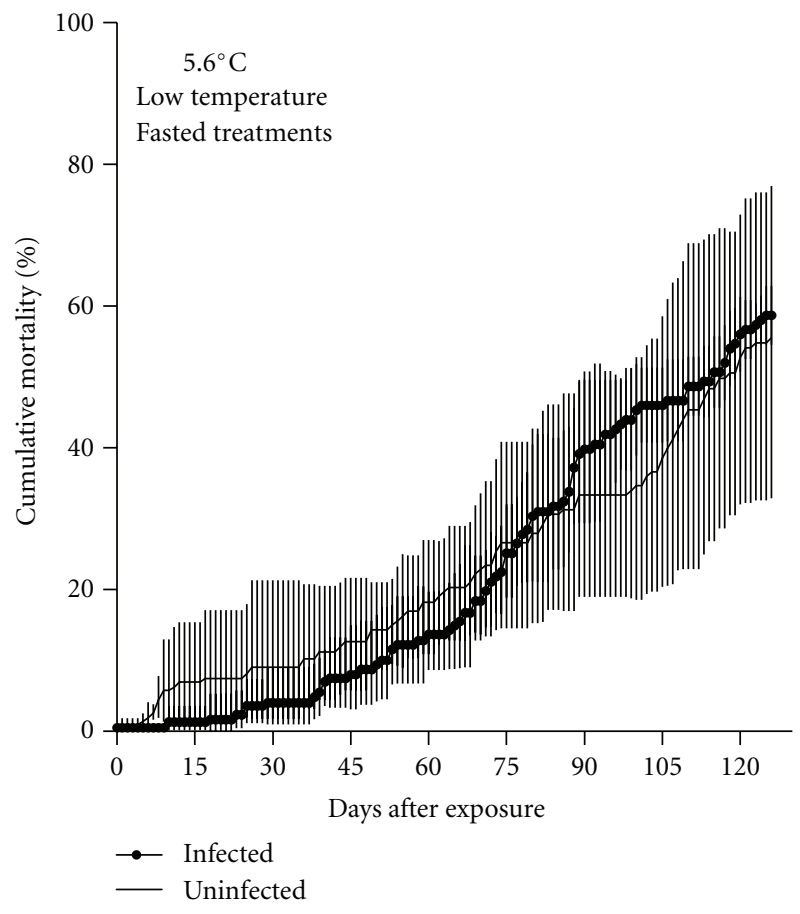

(a)

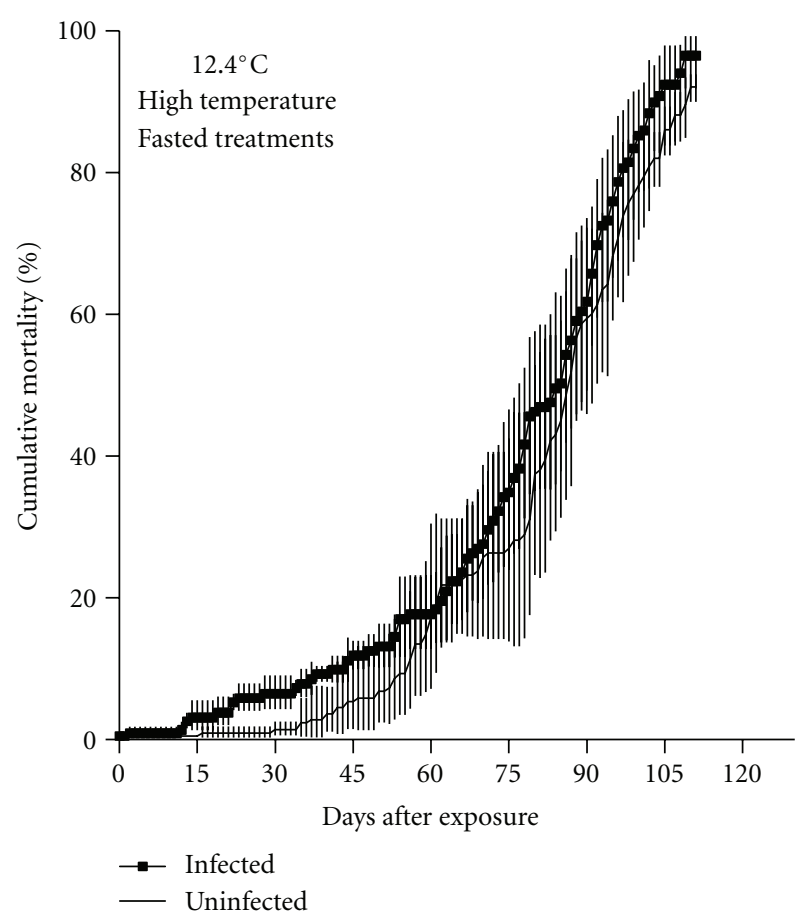

(c)

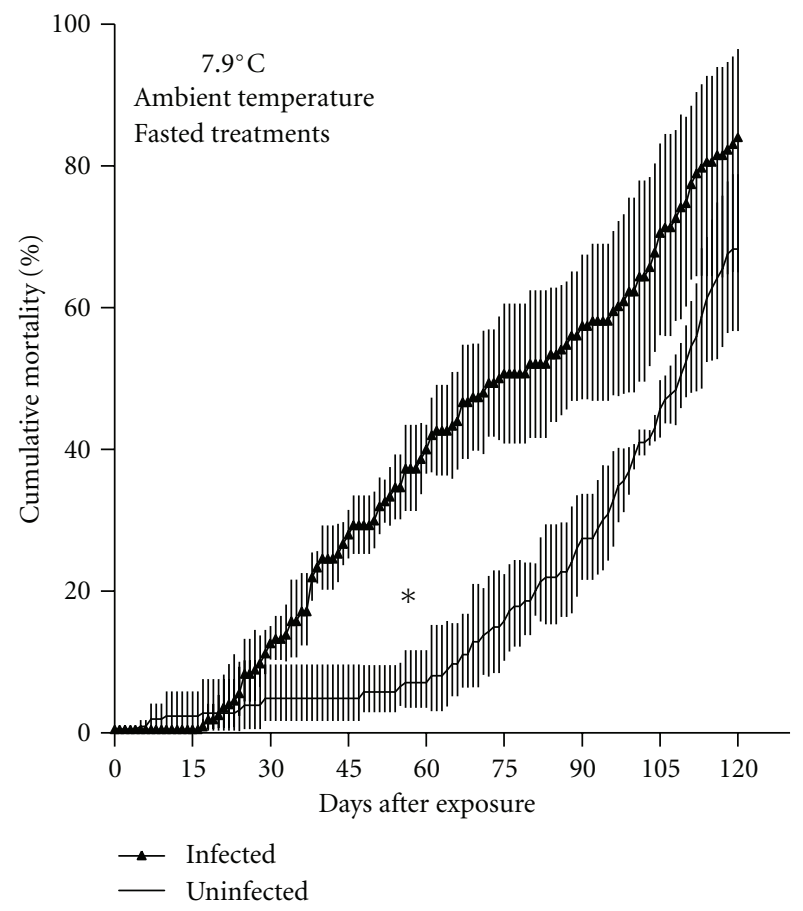

(b)

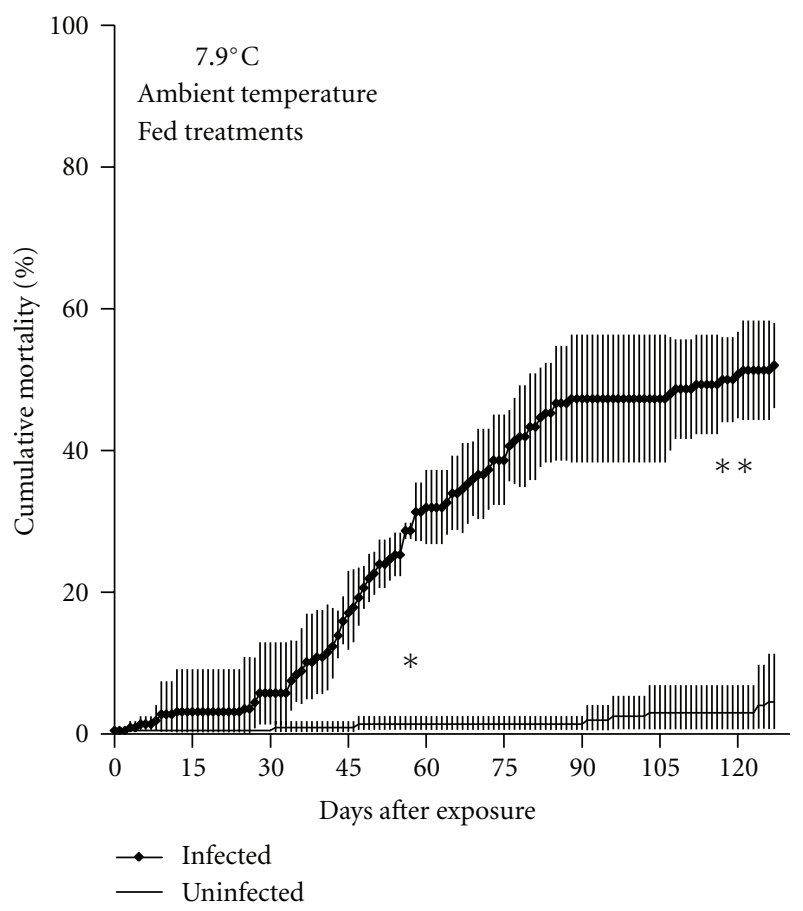

(d)

Figure 2: Clupea pallasii. Cumulative mortality of infected (Ichthyophonus) and control Pacific herring in three temperature treatments. Data in (a), (b), and (c) are from fish undergoing simulated overwinter fast. Data in (d) are from fed treatments. Ichthyophonus inoculation occurred on day 0, temperature adjustments on day 1. Data are means of 3 replicate tanks in each treatment. Error bars are one SD above and below the mean. Means and SD were calculated from arcsine-transformed data. Significant differences between infected and uninfected groups (Tukey multiple comparisons) indicated by $*$ and $* *$ for midpoint and end of challenge, respectively. 


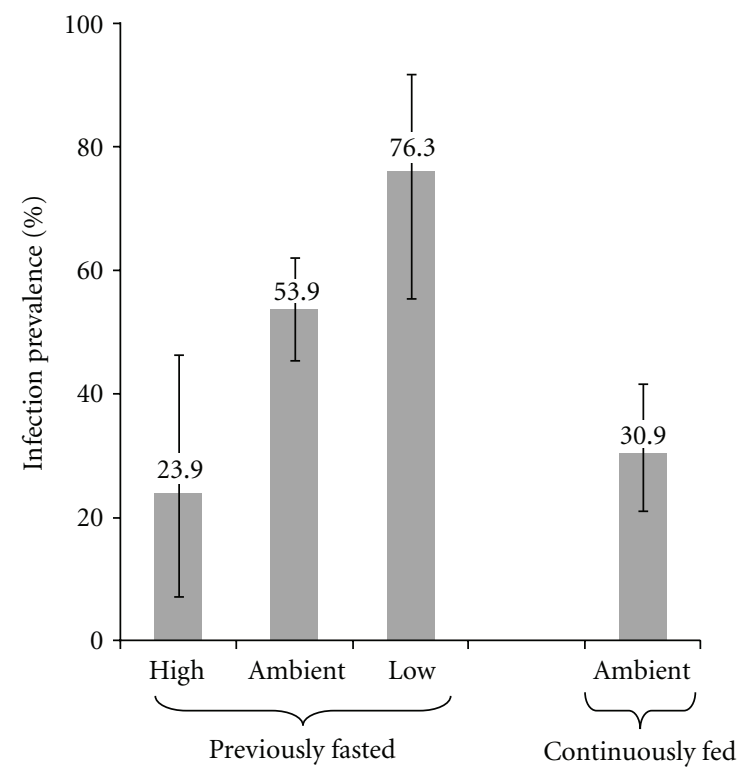

Figure 3: Clupea pallasii. Ichthyophonus infection prevalence in groups of Pacific herring held at three temperatures. Data are means of arcsine transformed data from 3 replicate tanks; error bars are one SD above and below the mean. Mean temperatures were $9.3^{\circ} \mathrm{C}$, $12.0^{\circ} \mathrm{C}$, and $15.3^{\circ} \mathrm{C}$ for low, ambient, and high treatments, respectively. Prechallenge fast lasted 56 days, after which fish were inoculated with Ichthyophonus, separated to treatments, and fed to satiation daily. ANOVA and Tukey test for multiple comparisons indicates that high-temperature treatment and continuously fed treatments are significantly different from low-temperature treatment.

and eventually an adaptive response in tissues [26, 27]. Ichthyophonus has been shown to elicit a cell mediate innate immune response in plaice (Pleuronectes platessa), haddock (Melanogrammus aeglefinus), and rainbow trout (O. mykiss) with persistent infections resulting in focal granulomata that encapsulate the parasite [13]. An antibody response has been demonstrated in plaice, but there is no evidence that it is protective [28].

The suppression of Ichthyophonus by a temperatureenhanced innate response is a plausible explanation for the reduced Ichthyophonus mortality that we observed in the newly exposed high-temperature treatment. This hypothesis is further supported by prevalence data from the preexposure fast challenge, where $76 \%, 54 \%$, and $24 \%$ of fish were infected in the low, ambient, and high temperature fasted/fed, treatments, respectively (Figure 3 ). The relative dose of Ichthyophonus decreased over the course of this study as fish mass increased (Table 1). In the third challenge, fasted fish received 17 schizonts $\mathrm{g}^{-1}$. At this dose, a fraction of the fish were able to clear the schizonts and prevent establishment of infection, and the number that was able to do so was markedly $(3 \mathrm{x})$ higher in the high-temperature treatment. This phenomenon was not evident in the sec-

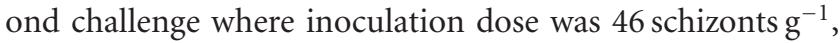
suggesting that high-parasite load can mask temperature effects. The importance of parasite load/dose in determining disease outcome is also evident in comparison of ambient treatments in the third challenge. Previously fasted fish received 17 schizonts $\mathrm{g}^{-1}$, while continuously fed received 12 schizonts $\mathrm{g}^{-1}$, resulting in mean infection prevalence of $54 \%$ and $31 \%$, respectively (Figure 3 ).

The temperature-driven variation demonstrated in this study has implications for our understanding of disease processes in wild herring populations. The temperatures used $\left(5.6^{\circ} \mathrm{C}\right.$ to $\left.15.3^{\circ} \mathrm{C}\right)$ are within those that the host species can experience across its geographic distribution [29-32], and the magnitude of temperature variation used in each challenge $\left(5-6^{\circ} \mathrm{C}\right)$ could plausibly be experienced by a single individual as the result of season temperature fluctuation and migration $[14,33]$. We did not see temperature effects in diseased fish but did see differences at early stages of infection, especially when exposure dose was low, suggesting that seawater temperature at time of exposure could be an important factor that determines disease prevalence over ensuing months and years. Unfortunately, the complete life cycle of Ichthyophonus is not known, and whether or not the disease is monoxenous in Pacific herring is still unclear. Other species such as rainbow trout, haddock, and plaice can become infected by eating infected fish tissues [11, 13], but the route of infection in Pacific herring is still in question. Juveniles captured shortly after metamorphosis are infected when they are still obligate planktivores [9]. Future field surveys and empirical studies should focus on closing the life history gaps that exist for Ichthyophonus, specifically the modality and timing of infection in Pacific herring. Once these variables are understood, more focused work could incorporate the findings of this study to mimic possible environmental processes at the time of infection.

\section{Acknowledgments}

Funding was provided by the Exxon Valdez Oil Spill Trustee Council, Projects nos. 1010086, 090806, 080806, and 070819 and U.S. Geological Survey Fisheries and Aquatic Resources Program. Technical assistance was provided by L. Taylor and M. Denny (USGS-MMFS). Custom made fish feed was offered in kind by Ann Gannam (USFWS). The use of trade, firm, or corporation names in this paper is for the information and convenience of the reader. Such use does not constitute an official endorsement or approval by the U.S. Department of Interior or the U.S. Geological Survey of any product or service to the exclusion of others that may be suitable.

\section{References}

[1] G. D. Marty, E. F. Freiberg, T. R. Meyers, J. Wilcock, T. B. Farver, and D. E. Hinton, "Viral hemorrhagic septicemia virus, Ichthyophonus hoferi, and other causes of morbidity in Pacific herring Clupea pallasi spawning in Prince William Sound, Alaska, USA," Diseases of Aquatic Organisms, vol. 32, no. 1, pp. 15-40, 1998.

[2] P. K. Hershberger, K. Stick, B. Bui et al., "Incidence of Ichthyophonus hoferi in Puget Sound fishes and its increase with age of Pacific herring," Journal of Aquatic Animal Health, vol. 14, no. 1, pp. 50-56, 2002. 
[3] S. R. M. Jones and S. C. Dawe, "Ichthyophonus hoferi Plehn \& Mulsow in British Columbia stocks of Pacific herring, Clupea pallasi Valenciennes, and its infectivity to chinook salmon, Oncorhynchus tshawytscha (Walbaum)," Journal of Fish Diseases, vol. 25, no. 7, pp. 415-421, 2002.

[4] P. K. Hershberger, C. A. Pacheco, J. L. Gregg, M. K. Purcell, and S. E. LaPatra, "Differential survival of Ichthyophonus isolates indicates parasite adaptation to its host environment," Journal of Parasitology, vol. 94, no. 5, pp. 1055-1059, 2008.

[5] C. Rasmussen, M. K. Purcell, J. L. Gregg, S. E. LaPatra, J. R. Winton, and P. K. Hershberger, "Sequence analysis of the internal transcribed spacer (ITS) region reveals a novel clade of Ichthyophonus sp. from rainbow trout," Diseases of Aquatic Organisms, vol. 89, no. 2, pp. 179-183, 2010.

[6] C. D. Criscione, V. Watral, C. M. Whipps, M. S. Blouin, S. R. M. Jones, and M. L. Kent, "Ribosomal DNA sequences indicate isolated populations of Ichthyophonus hoferi in geographic sympatry in the north-eastern Pacific Ocean," Journal of Fish Diseases, vol. 25, no. 10, pp. 575-582, 2002.

[7] G. D. Marty, T. J. Quinn, G. Carpenter, T. R. Meyers, and N. H. Willits, "Role of disease in abundance of a Pacific herring (Clupea pallasi) population," Canadian Journal of Fisheries and Aquatic Sciences, vol. 60, no. 10, pp. 1258-1265, 2003.

[8] H. Rahimian and J. Thulin, "Epizootiology of Ichthyophonus hoferi in herring populations off the Swedish west coast," Disease of Aquatic Organisms, vol. 27, no. 3, pp. 187-195, 1996.

[9] R. M. Kocan, P. Hershberger, T. Mehl et al., "Pathogenicity of Ichthyophonus hoferi for laboratory-reared Pacific herring Clupea pallasi and its early appearance in wild Puget Sound herring," Diseases of Aquatic Organisms, vol. 35, no. 1, pp. 2329, 1999.

[10] S. Kramer-Schadt, J. C. Holst, and D. Skagen, "Analysis of variables associated with the Ichthyophonus hoferi epizootics in Norwegian spring spawning herring, 1992-2008," Canadian Journal of Fisheries and Aquatic Sciences, vol. 67, no. 11, pp. 1862-1873, 2010.

[11] R. Kocan, S. LaPatra, J. Gregg, J. Winton, and P. Hershberger, "Ichthyophonus-induced cardiac damage: a mechanism for reduced swimming stamina in salmonids," Journal of Fish Diseases, vol. 29, no. 9, pp. 521-527, 2006.

[12] R. Kocan, P. Hershberger, G. Sanders, and J. Winton, "Effects of temperature on disease progression and swimming stamina in Ichthyophonus-infected rainbow trout, Oncor-hynchus mykiss (Walbaum)," Journal of Fish Diseases, vol. 32, no. 10, pp. 835-843, 2009.

[13] A. H. McVicar and H. A. McLay, "Tissue response of plaice, haddock, and rainbow trout to the systemic fungus Ichthyophonus," Fish and Shellfish Pathology, pp. 329-346, 1985.

[14] B. L. Norcross, E. D. Brown, R. J. Foy et al., "A synthesis of the life history and ecology of juvenile Pacific herring in Prince William Sound, Alaska," Fisheries Oceanography, vol. 10, no. 1, pp. 42-57, 2001.

[15] S. A. Hart, "The effect of temperature and media type on the production of Ichthyophonus in vitro," unpublished Student Papers, Emerging Diseases and Latent Infections in Aquatic Organisms. University of Washington, Friday Harbor Laboratories: Friday Harbor, Wash, USA, 2003.
[16] B. Spanggaard and H. H. Huss, "Growth of the fish parasite Ichthyophonus hoferi under food relevant conditions," International Journal of Food Science and Technology, vol. 31, no. 5, pp. 427-432, 1996.

[17] R. A. Holt, J. E. Sanders, J. L. Zinn, J. L. Fryer, and K. S. Pilcher, "Relation of water temperature to Flexibacter columnaris infection in steelhead trout (Salmo gairdneri), coho (Oncorhynchus kisutch) and chinook (O. tshawytscha) salmon," Canadian Journal of Fisheries and Aquatic Sciences, vol. 32, no. 9, pp. 1553-1559, 1975.

[18] W. J. Groberg Jr., R. H. McCoy, K. S. Pilcher, and J. L. Fryer, "Relation of water temperature to infections of coho salmon (Oncorhynchus kisutch), chinook salmon (O. tsawytscha) and steelhead trout (Salmo gairdneri) with Aeromonas salmonicida and A. hydrophila," Canadian Journal of Fisheries and Aquatic Sciences, vol. 35, no. 1, pp. 1-7, 1978.

[19] B. Magnadóttir, "Innate immunity of fish (overview)," Fish \& Shellfish Immunology, vol. 20, no. 2, pp. 137-151, 2006.

[20] M. Watts, B. L. Munday, and C. M. Burke, "Immune responses of teleost fish," Australian Veterinary Journal, vol. 79, no. 8, pp. 570-574, 2001.

[21] T. J. Bowden, K. D. Thompson, A. L. Morgan, R. M. L. Gratacap, and S. Nikoskelainen, "Seasonal variation and the immune response: a fish perspective," Fish \& Shellfish Immunology, vol. 22, no. 6, pp. 695-706, 2007.

[22] C. Le Morvan, D. Troutaud, and P. Deschaux, "Differential effects of temperature on specific and nonspecific immune defences in fish," Journal of Experimental Biology, vol. 201, no. 2, pp. 165-168, 1998.

[23] H. Boshra, J. Li, and J. O. Sunyer, "Recent advances on the complement system of teleost fish," Fish \& Shellfish Immunology, vol. 20, no. 2, pp. 239-262, 2006.

[24] L. J. Hardie, T. C. Fletcher, and C. J. Secombes, "Effect of temperature on macrophage activation and the production of macrophage activating factor by rainbow trout (Oncorhynchus mykiss) leucocytes," Developmental and Comparative Immunology, vol. 18, no. 1, pp. 57-66, 1994.

[25] M. Alishahi and K. Buchmann, "Temperature-dependent protection against Ichthyophthirius multifiliis following immunisation of rainbow trout using live theronts," Diseases of Aquatic Organisms, vol. 72, no. 3, pp. 269-273, 2006.

[26] K. Buchmann, J. Sigh, C. V. Nielsen, and M. Dalgaard, "Host responses against the fish parasitizing ciliate Ichthyophthirius multifiliis," Veterinary Parasitology, vol. 100, no. 1-2, pp. 105116, 2001.

[27] S. R. M. Jones, "The occurrence and mechanisms of innate immunity against parasites in fish," Developmental and Comparative Immunology, vol. 25, no. 8-9, pp. 841-852, 2001.

[28] A. H. McVicar, "Ichthyophonus and related organisms," in Fish Diseases and Disorders, Viral, Bacterial and Fungal Infections, P. T. K. Woo and D. W. Bruno, Eds., pp. 661-687, CABI Publishing, New York, NY, USA, 1999.

[29] D. R. Lassuy, "Species profiles: life histories and environmental requirements of coastal fishes and invertebrates (Pacific Northwest)_Pacific herring," Biological Report_US Fish \& Wildlife Service, vol. 82, no. 11, 1989.

[30] A. Huyer, "Seasonal variation in temperature, salinity, and density over the continental shelf off Oregon," Limnology and Oceanography, vol. 22, no. 3, pp. 442-453, 1977.

[31] S. K. Moore, N. J. Mantua, J. A. Newton, M. Kawase, M. J. Warner, and J. P. Kellogg, "A descriptive analysis of temporal and spatial patterns of variability in Puget Sound oceanographic properties," Estuarine, Coastal and Shelf Science, vol. 80, no. 4, pp. 545-554, 2008. 
[32] B. C. Weare, A. R. Navato, and R. E. Newell, "Empirical orthogonal analysis of pacific sea surface temperatures," Journal of Physical Oceanography, vol. 6, no. 5, pp. 671-678, 1976.

[33] D. J. Miller and J. Schmidtke, "Report on the distribution and abundance of Pacific herring (Clupea pallasi) along the coast of Central and Southern California," California Fish and Game, vol. 42, pp. 163-187, 1956. 

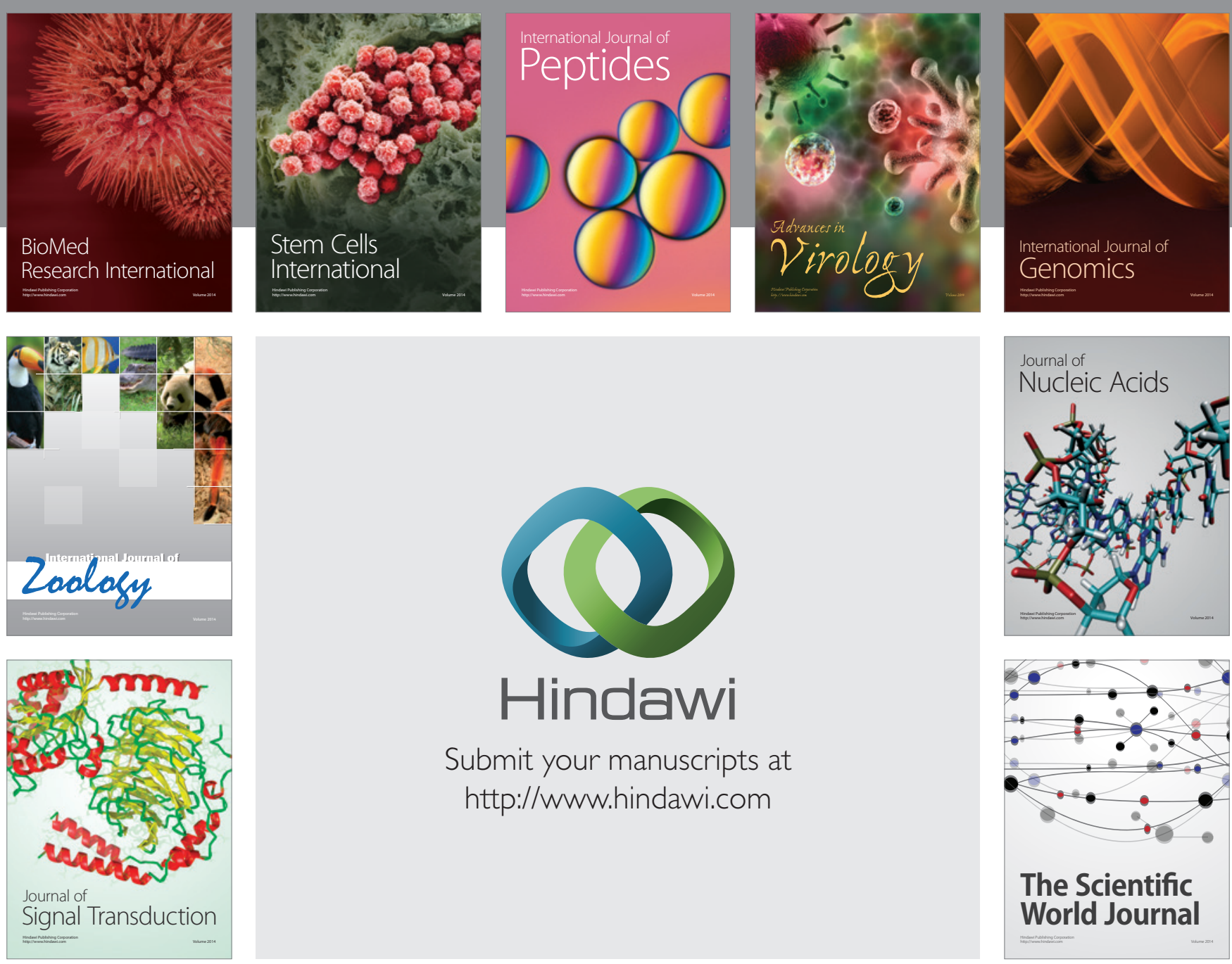

Submit your manuscripts at

http://www.hindawi.com
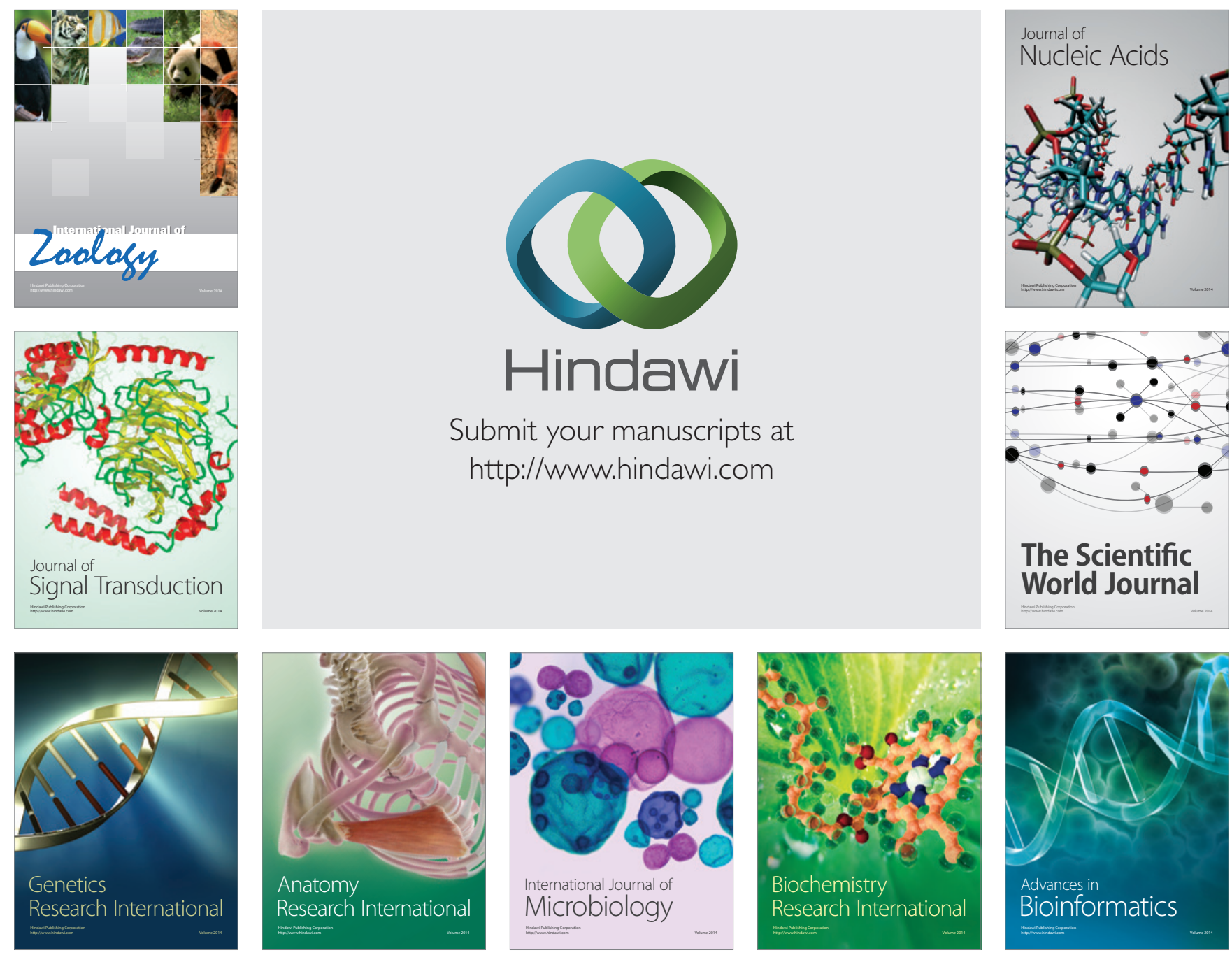

The Scientific World Journal
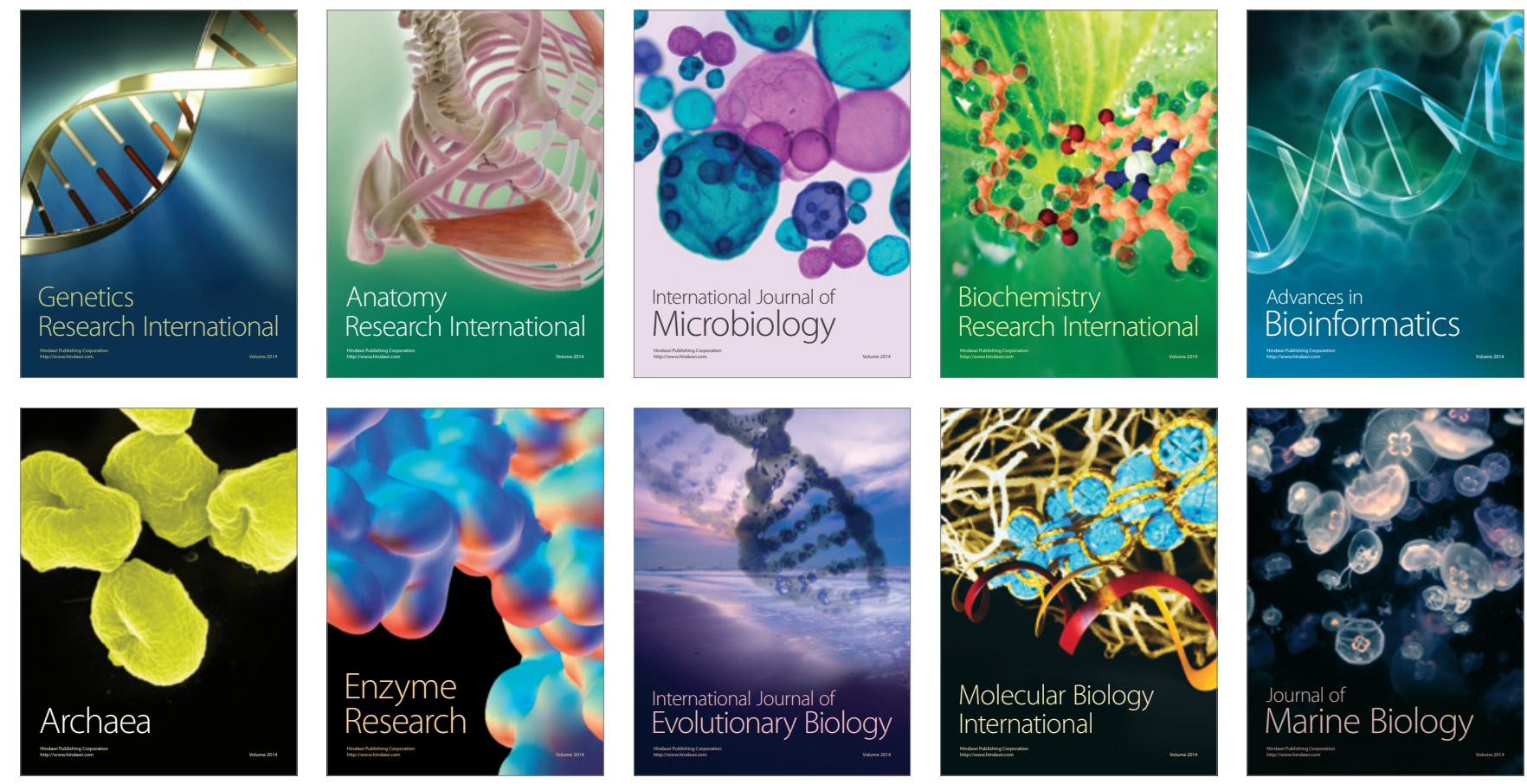